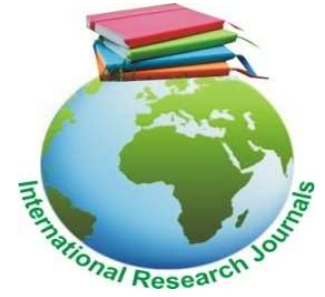

International Research Journal of Agricultural Science and Soil Science (ISSN: 2251-0044) Vol. 7(2) pp. 029-039, April, 2017

DOI: http:/dx.doi.org/10.14303/irjas.2017.031

Available online http://www.interesjournals.org/IRJAS

Copyright (C) 2017 International Research Journals

Full Length Research Paper

\title{
Influence of vines production methods and their combination with time of harvest on tuber quality and yield of sweet potato
}

\author{
Adeniyan, $\mathbf{O}$. N. \\ Institute of Agricultural Research and Training, Obafemi Awolowo University (OAU) P. M. B. 5029 Ibadan, Nigeria \\ Corresponding author's E-mail: adeniyantayo@yahoo.com
}

\begin{abstract}
Availability of sufficient sweet potato vines is usually a problem during the planting season because most of the sweet potato vines from the previous harvest dry up before the next planting season. Also, in the process whereby the farmers are resulted to the prolonged multiplication of old vines for the planting of the new fields, the yield and quality of harvested tubers are reduced due to vines degeneration, diseases and pests infestation. Therefore, trials were conducted at Ajase-Ipo community of Irepodun local government area in Kwara state and Ifon community of Ose local government area in Ondo state of Nigeria in 2008 and 2009 to investigate vines producing methods and and their combination with different time of harvest. Three vines production methods investigated are nurseries, vines from sprouts roots and vines from successive planting (Farmers' practice) and the harvesting time of sweet potato are 120, 140, 160 and 180 days after planting (DAP). The results indicated that, the effects of the vines production methods on the weight of fresh marketable tubers, weight of fresh unmarketable tubers, weight of total fresh tubers, tuber dry matter content and harvest index were significant. At both locations, nursery method gave the significantly highest values (15.2 and $13.8 \mathrm{t} / \mathrm{ha}$ ) for marketable tubers in 2008 and 2009 at Ajase Ipo and (17.4 and $15.2 \mathrm{t} / \mathrm{ha}$ ) at Ifon compared to sprouted roots and successive planting methods (Farmers' practice). The combination of the methods of vines production and time of harvest effects significantly affected the average weight of marketable tubers at Ajase Ipo and Ifon. Nursery method gave the significantly highest values [(13.5 and 15.8 t/ha), (11.8 and $12.9 \mathrm{t} / \mathrm{ha}),(9.4$ and $9.8 \mathrm{t} / \mathrm{ha})$ and (8.4 and $7.9 \mathrm{t} / \mathrm{ha})]$ at Ajase Ipo and Ifon at 120, 140, 160, and 180 days after planting (DAP) respectively compared to sprouted roots and successive planting methods. The combination of the methods of vines production and the time of harvest effects significantly affected the average weight of weevil free marketable tubers and badly infected marketable tubers at Ajase Ipo and Ifon. Consistently, nursery method gave the significantly highest values [(13.5 and $15.8 \mathrm{t} / \mathrm{ha}),(12.9$ and $14.8 \mathrm{t} / \mathrm{ha}),(10.3$ and $13.1 \mathrm{t} / \mathrm{ha})$ and $(8.6$ and $11.8 \mathrm{t} / \mathrm{ha})$ ] weevil free marketable tubers at Ajase Ipo and Ifon at 120,140,160, and 180 DAP respectively compared to sprouted roots and successive planting methods that were not significantly different from each other. But, the least values [(6.9 and 7.3 t/ha), (5.8 and 4.1 t/ha), (4.8 and 3.1 t/ha) and (1.6 and 2.3 t/ha)] at Ajase Ipo and Ifon at 120, 140,160 , and 180 DAP respectively were recorded for successive planting method.
\end{abstract}

Keywords: Sweet potato vines, Multiplication, Ajase Ipo, Ifon, Nursery, Sprouted roots, Successful planting.

\section{INTRODUCTION}

Sweet potato (Ipomoea batata) is one of the major world's most important and widely cultivated staple starchy food crops (FAO 2010). In Africa, the food crop is referred to as a minor secondary crop that is popular amongst resources-poor farmers (Mukhtar, 2010). Furthermore in some parts of Africa, sweet potato is 
processed into chips and flour that could be stored and later be converted to commercial products like bread and cakes, or processed into fermented and dried products like fufu (Oke and Worhneh, 2013). In Asia, sweet potato is important amongst the farmers, but it is mainly consumed as a staple food and it has not been reported to have entered into the international markets either in the fresh state or in a processed form (Mukhtar, 2010).

However in United States of America, sweet potato annual production has increased because it is been consumed as a staple food and also been processed as a canned food products (U.S. Sweet Potato Council, 2011). It has been reported that, sweet potato is highly useful in the large scale production of biomass suitable for conversion to industrial products like simple sugar for the production of alcohol (Ziska et al; 2009; Klass, 1998; Collins, 1984), and animal feeds (Posas, 1989). The traditional method of propagating sweet potato is mostly by the use of rooted sprouts from tubers or vine cuttings (Loebenstein and Thottapply, 2009). For enhanced yield and sustainable production of quality sweet potato, the propagation through rooted sprouts derived from tubers for direct planting has since been discouraged as a general practice in sweet potato production, because it usually results in low yield (Ikemoto, 1971). Shanmugavelu et al; (1972) had intimated that, sweet potato propagation should strictly be through vine cuttings. Some of the reasons adduced for supporting propagation through vine cuttings by the researchers are thus: plants derived from vine cuttings are free from soilborne diseases, the entire tuber harvested can be saved for consumption or marketing instead of reserving some of it for planting purposes. Shanmugavelu et al; (1972) intimated that, vine cuttings yield better than sprouts, and produce tubers of more uniform size and shape.

Therefore, the importance of providing sufficient vines as planting materials in sweet potato production cannot be over-emphasized. Availability of sufficient sweet potato vines is usually a problem during the planting season because most of the sweet potato vines from the previous harvest dry up before the next planting season. Also, in the process whereby the farmers are resulted to the prolonged multiplication of old vines for the planting of the new fields, the yield and quality of harvested tubers are reduced due to vines degeneration, diseases and pests infestation. The most serious insect pest of sweet potato has proven to be the sweet potato weevil. The pest may be passed from field to field through vines from the old and infested field. Healthy vines selection is of the very first importance in sweet potato production from the standpoint of controlling pests and diseases (Shanmugavelu et al; 1972). A number of pests and diseases seriously affect sweet potato in the field and unless care is taken to choose clean healthy vines. If this is not strictly adhered to, these diseases and pests may be carried into storage and later into the new field where they are transmitted to the propagating plant stock. One of the greatest problems mitigating against a successful storage of sweet potato is the transferring from the field pests which would never have been present had proper precautions been taken in selecting the tubers that produce vines which produced the field crop. Consequently, methods for mass production of sweet potato vines will be of immense benefit in the large-scale production of sweet potato. Therefore, keeping in view the importance of producing healthy and sufficient potato vines and the importance of timely harvesting of marketable and pest free fresh tubers on sweet potato production, an on-farm trial was designed to evaluate their efficacy in sustainable sweet potato production.

Hence the objectives of these trials were to evaluate the tuber yield and quality under the production of vines for planting from nurseries, sprout from storage roots and planting materials from successive field (Farmers' practice) in combination with time of harvest at 120, 140, 160 and 180 days after planting (DAP) of sweet potato and to recommend the strategy that can be adopted to ensure an adequate supply of healthy vine cuttings at planting time and enhanced sweet potato productivity.

\section{MATERIALS AND METHODS}

The trials were carried out in the sweet potato producing areas; Ajase-Ipo community of Irepodun local government area in Kwara state and Ifon community of Ose local government area in Ondo state of Nigeria in 2008 and 2009. In both years of experimentation, during the non-growing season corresponds to the dry season the production of the sweet potato vines for planting materials was undertaking, during the growing season corresponds to the raining season the establishment of the experimental fields was carried out. Ajase-lpo is located at latitude $8^{\circ} 13^{\prime}$ north and longitude $4^{\circ} 49^{\prime}$ east as displayed on world map coordinates and short location facts. The town serves as major junction for all other major cities and towns in Kwara State, Nigeria including Ilorin (Kwara State capital), Omu-Aran, Offa and Igbaja. The vegetation type of the community is mainly guinea savannah with the climatic condition revealing a marked dry and wet season (Bolaji et al; 2015). While Ifon is located at latitude $6^{\circ} 92^{\prime}$ north and longitude $5^{\circ} 77^{\prime}$ east as displayed on world map coordinates and short location facts. The town serves as major community along AkureOwo-Benin major road. The vegetation type of the community is mainly rain forest with the climatic condition revealing a marked dry and wet season.

In 2008 during the non-growing season, nursery plots for production and maintaining of sweet potato vines as planting materials for the main trials were established close to a stream banks at the experimental communities. The vines for the establishment of the nursery plots were sourced for from a healthy field of previous harvest as suggested by Onwueme, (1978). The production of vines 
from the sprouted tubers was also carried out by establishing another nursery plots at the stream bank by sourcing for healthy and pest free tubers from the previous harvest. Whole small tubers and slices from bigger tubers were spaced closer together, covered lightly with soil. Plots were kept weed free by regular manual weeding. Mineral fertilizer; NPK 15:15:15 was applied 4 weeks after planting (WAP).

The main experiments were conducted during the rainy season of 2008 and 2009 . The sites were cleared, ploughed, harrowed and made into $0.75 \mathrm{~m}$ row ridges. The experiment was set up as a randomized complete block design (RCBD) with split-plot arrangements, having four replications. Three vines production methods; nurseries, vines from sprouts from storage roots and vines from successive planting (Farmers' practice) were assigned to the main-plots and three harvest time were assigned to the sub-plot. Individual plot consists of five rows of $5 \mathrm{~m}$ long and $0.75 \mathrm{~m}$ apart. The plot size was $4 \mathrm{x}$ $5 \mathrm{~m}$. Plots were kept weed free by regular manual weeding. Mineral fertilizer; NPK 15:15:15 was applied 4 weeks after planting (WAP). Data were collected on the weights of marketable and unmarketable fresh tuber yields. The total fresh tuber yield was recorded by adding the weight of the marketable and the unmarketable fresh tuber yields. The dry matter content was determined by drying in an oven at $70^{\circ} \mathrm{C}$ for 24 hours to constant weight. The amount of dried pulp of sweet potato tubers from $100 \mathrm{~g}$ of fresh pulp of sweet potato tubers was weight. The dry matter content was expressed as follows:

Dry matter content $=100 \times(\mathrm{W} 2 / \mathrm{W} 1)$

Where,

W2 = the weight of dried pulp of tubers

$\mathrm{W} 1$ = the weight of fresh pulp of tubers.

The above ground biomass yield per hectare at harvest was determined.

Harvest index percentage was determined as follows:

Harvest index $(\%)=$ WFST/WFST + ABY $\times 100$

Where,

WFST $=$ weight of fresh storage tubers

$A B Y=$ above ground biomass yield.

The effect of weevil infestation of tubers was recorded at harvest. The data collected were subjected to analysis of variance (ANOVA), using F - test as described by Snedecor and Cochran (1967). Where the treatments were found to be significantly different, the means were compared using Duncan Multiple Range Test (DMRT) (Duncan, 1955).

\section{RESULTS AND DISCUSSION}

\section{Effects of vines production methods on yield and yield components}

The effects of the vines production methods on the weight of fresh marketable tubers, weight of fresh unmarketable tubers, weight of total fresh tubers, tuber dry matter content and harvest index were significant $(P<$ 0.05) in 2008 and 2009 at Ajase Ipo, Kwara state and Ifon, Ondo state (Tables 1 and 2). At both locations, nursery method gave the significantly highest values (15.2 and $13.8 \mathrm{t} / \mathrm{ha}$ ) for marketable tubers in 2008 and 2009 at Ajase Ipo and (17.4 and 15.2 t/ha) at Ifon compared to sprouted roots and successive planting methods (Farmers' practice). Inversely, the nursery method of vines production recorded significantly least values ( 0.6 and $0.4 \mathrm{t} / \mathrm{ha}$ ) for unmarketable tubers at Ajase Ipo and (0.4 and 0.5 t/ha) at Ifon in 2008 and 2009 compared to sprouted roots and successive planting methods. The results validated the suggestions of Ikemoto (1971) and Shanmugavelu et al; (1972) that sweet potato should be strictly propagated through vine cuttings. They reported that, vine cuttings yielded better than sprouts, and produced tubers of more uniform size and shape.

There were however, significantly highest values (15.8 and $14.2 \mathrm{t} / \mathrm{ha}$ ) for total weight of fresh tubers in 2008 and 2009 at Ajase Ipo and (17.8 and $15.7 \mathrm{t} / \mathrm{ha}$ ) at Ifon for nursery method compared to sprouted roots and successive planting methods. For enhanced yield and sustainable production of quality sweet potato, the propagation through sprouted roots derived from tubers for direct planting has since been discouraged as a general practice in sweet potato production, because it usually results in low yield (Ikemoto 1971). Similarly, significantly highest values for tuber dry matter content values (37.4 and $35.9 \%$ ) in 2008 and 2009 at Ajase Ipo and (38.4 and $39.5 \%)$ at Ifon were recorded for nursery method compared to sprouted roots and successive planting methods.

Also, nursery method gave the significantly highest values (69.4 and $74.3 \%$ ) for harvest index in 2008 and 2009 at Ajase Ipo and (68.3 and $77.3 \%)$ at Ifon compared to sprouted roots and successive planting methods. Successive cutting of vines from the established sweet potato field to plant other portion of the field as it was in the case of successive planting method reduced harvest index.

This might have stemmed from the disruption in growth and development of leaves caused by the vine cutting which might have reduced leaf surface area for photosynthesis. Nwinyi (1992) has reported that removal of sweet potato vines during growth reduced the supply of photosynthetic products in the remaining period of growth of the plant with an eventual reduction in tuber yields. Corroborating the results of this study, Klozya et al; (2001) and Nguyen and Bautista (1999) also reported that harvesting the vines from successive plant for further planting reduced yields of tubers of sweet potato. Similarly, Stathers et al; (2005) reported that tuber yield of sweet potato was significantly reduced when cuttings were taking from young plants during early growth for propagation. 
032 Int. Res. J. Agric. Sci. Soil Sci.

Table 1: Effects of vines production methods on yield and yield components of sweet potato in 2008 and 2009 at Ajase-Ipo, Kwara state.

\begin{tabular}{lcccccccccc}
\hline Treatments & $\begin{array}{c}\text { Weight of } \\
\text { marketable } \\
\text { tubers (t/ha) }\end{array}$ & \multicolumn{2}{c}{$\begin{array}{c}\text { Weight of } \\
\text { unmarketable } \\
\text { tubers (t/ha) }\end{array}$} & $\begin{array}{c}\text { Total weight } \\
\text { of fresh } \\
\text { tubers (t/ha) }\end{array}$ & \multicolumn{2}{c}{$\begin{array}{c}\text { Tuber dry } \\
\text { matter } \\
\text { content (\%) }\end{array}$} & \multicolumn{2}{c}{$\begin{array}{c}\text { Harvest index } \\
\text { (\%) }\end{array}$} \\
\hline & 2008 & 2009 & 2008 & 2009 & 2008 & 2009 & 2008 & 2009 & 2008 & 2009 \\
Nursery & $15.2 \mathrm{a}$ & $13.8 \mathrm{a}$ & $0.6 \mathrm{c}$ & $0.4 \mathrm{c}$ & $15.8 \mathrm{a}$ & $14.2 \mathrm{a}$ & $37.4 \mathrm{a}$ & $35.9 \mathrm{a}$ & $69.4 \mathrm{a}$ & $74.3 \mathrm{a}$ \\
Sprouted roots & $9.7 \mathrm{~b}$ & $8.3 \mathrm{~b}$ & $1.2 \mathrm{~b}$ & $0.8 \mathrm{~b}$ & $10.9 \mathrm{~b}$ & $9.1 \mathrm{~b}$ & $28.6 \mathrm{~b}$ & $27.8 \mathrm{~b}$ & $55.8 \mathrm{~b}$ & $48.7 \mathrm{~b}$ \\
Successive planting & $6.2 \mathrm{~b}$ & $8.9 \mathrm{~b}$ & $1.8 \mathrm{a}$ & $1.6 \mathrm{a}$ & $8.0 \mathrm{~b}$ & $10.5 \mathrm{~b}$ & $26.1 \mathrm{~b}$ & $27.2 \mathrm{~b}$ & $47.4 \mathrm{c}$ & $38.9 \mathrm{c}$ \\
\hline
\end{tabular}

Means having the same letter are not significantly different $(P=0.05)$ according to Duncan's Multiple Range Test.

Table 2: The effects of vines production methods on yield and yield components of sweet potato in 2008 and 2009 at Ifon, Ondo state

\begin{tabular}{lcccccccccc}
\hline Treatments & $\begin{array}{c}\text { Weight of } \\
\text { marketable } \\
\text { tubers (t/ha) }\end{array}$ & \multicolumn{2}{c}{$\begin{array}{c}\text { Weight of } \\
\text { unmarketable } \\
\text { tubers (t/ha) }\end{array}$} & $\begin{array}{c}\text { Total weight } \\
\text { of fresh } \\
\text { tubers (t/ha) }\end{array}$ & $\begin{array}{c}\text { Tuber dry } \\
\text { matter content } \\
\text { (\%) }\end{array}$ & $\begin{array}{c}\text { Harvest index } \\
\text { (\%) }\end{array}$ \\
\hline Nursery & 2008 & 2009 & 2008 & 2009 & 2008 & 2009 & 2008 & 2009 & 2008 & 2009 \\
Sprouted roots & $17.4 \mathrm{a}$ & $15.2 \mathrm{a}$ & $0.4 \mathrm{c}$ & $0.5 \mathrm{c}$ & $17.8 \mathrm{a}$ & $15.7 \mathrm{a}$ & $38.4 \mathrm{a}$ & $39.5 \mathrm{a}$ & $68.3 \mathrm{a}$ & $77.3 \mathrm{a}$ \\
Successive planting & $11.3 \mathrm{~b}$ & $10.3 \mathrm{~b}$ & $0.9 \mathrm{~b}$ & $1.1 \mathrm{~b}$ & $12.2 \mathrm{~b}$ & $11.4 \mathrm{~b}$ & $30.2 \mathrm{~b}$ & $25.9 \mathrm{~b}$ & $49.6 \mathrm{~b}$ & $55.9 \mathrm{~b}$ \\
\hline
\end{tabular}

Means having the same letter are not significantly different $(P=0.05)$ according to Duncan's Multiple Range Test.

Table 3: The combined effects of vines production methods and time of harvest on the average weight of marketable tubers of sweet potato in 2008 and 2009 at Ajase-Ipo, Kwara state and Ifon, Ondo state

\begin{tabular}{|c|c|c|c|c|c|c|c|c|}
\hline \multirow{3}{*}{ Treatments } & \multicolumn{8}{|c|}{ Days to harvest of tubers } \\
\hline & \multicolumn{2}{|c|}{$\begin{array}{l}1^{\text {st }} \text { harvest } \\
\text { (120 DAP) }\end{array}$} & \multicolumn{2}{|c|}{$\begin{array}{c}2^{\text {nd }} \text { harvest } \\
\text { (140 DAP) }\end{array}$} & \multicolumn{2}{|c|}{$\begin{array}{l}3^{\text {rd }} \text { harvest } \\
\text { (160 DAP) }\end{array}$} & \multicolumn{2}{|c|}{$\begin{array}{l}4^{\text {th }} \text { harvest } \\
(180 \text { DAP) }\end{array}$} \\
\hline & $\begin{array}{c}\text { Ajase-Ipo } \\
\text { (t/ha) }\end{array}$ & $\begin{array}{l}\text { Ifon } \\
\text { (t/ha) }\end{array}$ & $\begin{array}{c}\text { Ajase-Ipo } \\
\text { (t/ha) }\end{array}$ & $\begin{array}{c}\text { Ifon } \\
\text { (t/ha) }\end{array}$ & $\begin{array}{c}\text { Ajase-Ipo } \\
\text { (t/ha) }\end{array}$ & $\begin{array}{c}\text { Ifon } \\
\text { (t/ha) }\end{array}$ & $\begin{array}{c}\text { Ajase-Ipo } \\
\text { (t/ha) }\end{array}$ & $\begin{array}{c}\text { Ifon } \\
\text { (t/ha) }\end{array}$ \\
\hline Nursery & $13.5 a$ & $15.8 a$ & $11.8 \mathrm{a}$ & $12.9 a$ & $9.4 a$ & $9.8 a$ & $8.4 a$ & $7.9 a$ \\
\hline Sprouted roots & $8.9 b$ & $9.4 b$ & $6.7 \mathrm{~b}$ & $7.1 b$ & $5.2 b$ & $5.5 b$ & $3.8 b$ & $3.1 \mathrm{~b}$ \\
\hline Successive planting & $6.9 \mathrm{~b}$ & $7.3 b$ & $4.7 \mathrm{~b}$ & $4.4 b$ & $2.5 \mathrm{c}$ & $2.9 \mathrm{c}$ & $1.5 \mathrm{c}$ & $1.2 \mathrm{c}$ \\
\hline
\end{tabular}

Means having the same letter are not significantly different $(P=0.05)$ according to Duncan's Multiple Range Test.

The combined effects of vines production methods and time of harvest on the average weight of marketable tubers

The combination of the methods of vines production and time of harvest effects significantly $(P<0.05)$ affected the average weight of marketable tubers at Ajase Ipo and Ifon (Table 3). Nursery method gave the significantly highest values [(13.5 and $15.8 \mathrm{t} / \mathrm{ha}),(11.8$ and $12.9 \mathrm{t} / \mathrm{ha})$, (9.4 and $9.8 \mathrm{t} / \mathrm{ha})$ and (8.4 and $7.9 \mathrm{t} / \mathrm{ha})]$ at Ajase Ipo and Ifon at 120,140,160, and 180 days after planting (DAP) respectively compared to sprouted roots and successive planting methods. The least significant values [(13.5 and $15.8 \mathrm{t} / \mathrm{ha}),(11.8$ and $12.9 \mathrm{t} / \mathrm{ha}),(9.4$ and $9.8 \mathrm{t} / \mathrm{ha}$ ) and (8.4 and $7.9 \mathrm{t} / \mathrm{ha})]$ at Ajase Ipo and Ifon at $120,140,160$, and 180 DAP respectively were recorded for successive planting method. The better yields obtained for nursery methods after the first harvest proved that the vines from this method have ability to produce high yield, and the yielded tubers could stay 
Table 4: The combined effects of vines production methods and time of harvest on the average weight of unmarketable tubers of sweet potato in 2008 and 2009 at Ajase-Ipo, Kwara state and Ifon, Ondo state

\begin{tabular}{|c|c|c|c|c|c|c|c|c|}
\hline \multirow{3}{*}{ Treatments } & \multicolumn{8}{|c|}{ Days to harvest of tubers } \\
\hline & \multicolumn{2}{|c|}{$\begin{array}{l}1^{\text {st }} \text { harvest } \\
(120 \text { DAP) }\end{array}$} & \multicolumn{2}{|c|}{$\begin{array}{c}2^{\text {nd }} \text { harvest } \\
\text { (140 DAP) }\end{array}$} & \multicolumn{2}{|c|}{$\begin{array}{c}3^{\text {rd }} \text { harvest } \\
\text { (160 DAP) }\end{array}$} & \multicolumn{2}{|c|}{$\begin{array}{l}4^{\text {th }} \text { harvest } \\
\text { (180 DAP) }\end{array}$} \\
\hline & $\begin{array}{c}\text { Ajase-Ipo } \\
\text { (t/ha) }\end{array}$ & $\begin{array}{c}\text { Ifon } \\
\text { (t/ha) }\end{array}$ & $\begin{array}{c}\text { Ajase-Ipo } \\
\text { (t/ha) }\end{array}$ & $\begin{array}{c}\text { Ifon } \\
\text { (t/ha) }\end{array}$ & $\begin{array}{c}\text { Ajase-Ipo } \\
\text { (t/ha) }\end{array}$ & $\begin{array}{c}\text { Ifon } \\
\text { (t/ha) }\end{array}$ & $\begin{array}{c}\text { Ajase-Ipo } \\
\text { (t/ha) }\end{array}$ & $\begin{array}{c}\text { Ifon } \\
\text { (t/ha) }\end{array}$ \\
\hline Nursery & $0.5 b$ & $0.8 b$ & $0.8 \mathrm{~b}$ & $1.3 b$ & $1.9 \mathrm{c}$ & $2.8 c$ & $2.7 \mathrm{c}$ & $3.1 \mathrm{c}$ \\
\hline Sprouted roots & $1.3 a$ & $1.5 \mathrm{a}$ & $2.3 a$ & $2.6 a$ & $3.3 b$ & $3.5 b$ & $4.8 \mathrm{~b}$ & $4.4 \mathrm{~b}$ \\
\hline Successive planting & $1.8 \mathrm{a}$ & $1.9 \mathrm{a}$ & $2.9 a$ & $2.8 \mathrm{a}$ & $3.8 \mathrm{a}$ & $3.9 a$ & $5.6 a$ & $5.9 a$ \\
\hline
\end{tabular}

Means having the same letter are not significantly different $(P=0.05)$ according to Duncan's Multiple Range Test.

Table 5: The combined effects of vines production methods and time of harvest on the average weight of total fresh tubers of sweet potato in 2008 and 2009 at Ajase-Ipo, Kwara state and Ifon, Ondo state

\begin{tabular}{|c|c|c|c|c|c|c|c|c|}
\hline \multirow{3}{*}{ Treatments } & \multicolumn{8}{|c|}{ Days to harvest of tubers } \\
\hline & \multicolumn{2}{|c|}{$\begin{array}{l}1^{\text {st }} \text { harvest } \\
\text { (120 DAP) }\end{array}$} & \multicolumn{2}{|c|}{$\begin{array}{c}2^{\text {nd }} \text { harvest } \\
\text { (140 DAP) }\end{array}$} & \multicolumn{2}{|c|}{$\begin{array}{c}3^{\text {rd }} \text { harvest } \\
\text { (160 DAP) }\end{array}$} & \multicolumn{2}{|c|}{$\begin{array}{l}4^{\text {th }} \text { harvest } \\
\text { (180 DAP) }\end{array}$} \\
\hline & $\begin{array}{c}\text { Ajase-Ipo } \\
\text { (t/ha) }\end{array}$ & $\begin{array}{l}\text { Ifon } \\
\text { (t/ha) }\end{array}$ & $\begin{array}{c}\text { Ajase-Ipo } \\
\text { (t/ha) }\end{array}$ & $\begin{array}{l}\text { Ifon } \\
\text { (t/ha) }\end{array}$ & $\begin{array}{c}\text { Ajase-Ipo } \\
\text { (t/ha) }\end{array}$ & $\begin{array}{l}\text { Ifon } \\
\text { (t/ha) }\end{array}$ & $\begin{array}{c}\text { Ajase-Ipo } \\
\text { (t/ha) }\end{array}$ & $\begin{array}{l}\text { Ifon } \\
\text { (t/ha) }\end{array}$ \\
\hline Nursery & $14.0 \mathrm{a}$ & $16.6 a$ & $12.6 a$ & $14.2 \mathrm{a}$ & $11.3 a$ & $12.6 a$ & $11.1 \mathrm{a}$ & $11.7 \mathrm{a}$ \\
\hline Sprouted roots & $10.0 \mathrm{~b}$ & $10.9 b$ & $9.0 \mathrm{~b}$ & $9.7 \mathrm{~b}$ & $9.7 \mathrm{~b}$ & $9.0 \mathrm{~b}$ & $7.6 b$ & $7.5 b$ \\
\hline Successive planting & $8.7 \mathrm{~b}$ & $9.2 b$ & $8.6 b$ & $8.2 b$ & $7.3 b$ & $8.8 \mathrm{~b}$ & $7.1 \mathrm{~b}$ & $7.1 \mathrm{~b}$ \\
\hline
\end{tabular}

Means having the same letter are not significantly different $(P=0.05)$ according to Duncan's Multiple Range Test.

longer in the soil.

\section{The combined effects of vines production methods and time of harvest on the average weight of unmarketable tubers}

The combination of methods of the vines production methods and the time of harvest effect significantly $(P<$ 0.05 ) affected the average weight of unmarketable tubers at Ajase Ipo and Ifon (Table 4). Successive planting method gave the significantly highest values [(1.8 and 1.9 t/ha), (2.9 and $2.8 \mathrm{t} / \mathrm{ha}),(3.8$ and $3.9 \mathrm{t} / \mathrm{ha})$ and (5.6 and $5.9 \mathrm{t} / \mathrm{ha})]$ at Ajase Ipo and Ifon at 120,140,160, and 180 DAP respectively. This was followed by sprouted roots method with the values [(1.3 and $1.5 \mathrm{t} / \mathrm{ha}),(2.3$ and 2.6 $\mathrm{t} / \mathrm{ha}),(3.3$ and $3.5 \mathrm{t} / \mathrm{ha})$ and (4.8 and $4.4 \mathrm{t} / \mathrm{ha})$ ] at Ajase Ipo and Ifon at 120,140,160, and 180 DAP respectively. However, the least significant values [ $(0.5$ and $0.8 \mathrm{t} / \mathrm{ha})$, (0.8 and $1.3 \mathrm{t} / \mathrm{ha}$ ), (1.9 and $2.8 \mathrm{t} / \mathrm{ha}$ ) and (2.7 and 3.1 t/ha)] at Ajase Ipo and Ifon at 120, 140, 160, and 180 DAP respectively were recorded for nursery method (Table 4). The results revealed that, the more the tubers from sprouted roots and successive planting methods stayed in the soil the higher the yield of unmarketable tubers. However, nursery method of producing vines produced less of unmarketable tubers as the tubers stayed longer in the soil.

The combined effects of vines production methods and time of harvest on the average weight of total fresh tubers

The combination of the methods of vines production and the time of harvest effects significantly $(P<0.05)$ affected the average weight of total fresh tubers at Ajase Ipo and Ifon (Table 5). Nursery method gave the significantly highest values [(14.0 and 16.6 t/ha), (12.6 and $14.2 \mathrm{t} / \mathrm{ha}$ ), (11.3 and $12.6 \mathrm{t} / \mathrm{ha}$ ) and (11.1 and $11.7 \mathrm{t} / \mathrm{ha})]$ at Ajase Ipo and Ifon at 120,140,160, and 180 DAP respectively compared to sprouted roots and successive planting methods that were not significantly different from each other. But, the least values [( 8.7 and $9.2 \mathrm{t} / \mathrm{ha}),(8.6$ and $8.2 \mathrm{t} / \mathrm{ha}),(7.3$ and $8.8 \mathrm{t} / \mathrm{ha})$ and $(7.1$ and $7.1 \mathrm{t} / \mathrm{ha})$ ] at Ajase Ipo and Ifon at 120, 140, 160, and 180 DAP respectively were recorded for successive planting method.

These results followed the same trend just like that of the yield of marketable tubers. 
034 Int. Res. J. Agric. Sci. Soil Sci.

Table 6: The combined effects of vines production methods and time of harvest on the average harvest index of tubers of sweet potato in 2008 and 2009 at Ajase-Ipo, Kwara state and Ifon, Ondo state

\begin{tabular}{|c|c|c|c|c|c|c|c|c|}
\hline \multirow{3}{*}{ Treatments } & \multicolumn{8}{|c|}{ Days to harvest of tubers } \\
\hline & \multicolumn{2}{|c|}{$\begin{array}{l}1^{\text {st }} \text { harvest } \\
\text { (120 DAP) }\end{array}$} & \multicolumn{2}{|c|}{$\begin{array}{l}2^{\text {nd }} \text { harvest } \\
\text { (140 DAP) }\end{array}$} & \multicolumn{2}{|c|}{$\begin{array}{l}3^{\text {rd }} \text { harvest } \\
\text { (160 DAP) }\end{array}$} & \multicolumn{2}{|c|}{$\begin{array}{c}4^{\text {th }} \text { harvest } \\
\text { (180 DAP) }\end{array}$} \\
\hline & $\begin{array}{c}\text { Ajase-Ipo } \\
(\%)\end{array}$ & $\begin{array}{l}\text { Ifon } \\
\text { (\%) }\end{array}$ & $\begin{array}{c}\text { Ajase-Ipo } \\
(\%)\end{array}$ & $\begin{array}{l}\text { Ifon } \\
(\%)\end{array}$ & $\begin{array}{c}\text { Ajase-Ipo } \\
(\%) \\
\end{array}$ & $\begin{array}{l}\text { Ifon } \\
(\%)\end{array}$ & $\begin{array}{c}\text { Ajase-Ipo } \\
(\%) \\
\end{array}$ & $\begin{array}{l}\text { Ifon } \\
(\%) \\
\end{array}$ \\
\hline Nursery & $71.9 a$ & $72.8 \mathrm{a}$ & $62.7 a$ & $60.8 a$ & $54.6 a$ & $50.3 a$ & $45.9 a$ & $43.5 a$ \\
\hline Sprouted roots & $52.3 b$ & $52.8 b$ & $44.9 \mathrm{~b}$ & $42.9 b$ & $33.9 b$ & $36.2 b$ & $29.6 b$ & $30.6 b$ \\
\hline Successive planting & $43.2 \mathrm{c}$ & $42.7 \mathrm{c}$ & $35.9 c$ & $32.3 \mathrm{c}$ & $24.6 c$ & $27.2 \mathrm{c}$ & $19.6 c$ & $22.7 c$ \\
\hline
\end{tabular}

Means having the same letter are not significantly different $(P=0.05)$ according to Duncan's Multiple Range Test.

Table 7: The combined effects of vines production methods and time of harvest on the average weight of weevil free marketable tubers of sweet potato in 2008 and 2009 at Ajase-Ipo, Kwara state and Ifon, Ondo state

\begin{tabular}{|c|c|c|c|c|c|c|c|c|}
\hline \multirow{3}{*}{ Treatments } & \multicolumn{8}{|c|}{ Days to harvest of tubers } \\
\hline & \multicolumn{2}{|c|}{$\begin{array}{l}1^{\text {st }} \text { harvest } \\
(120 \text { DAP) }\end{array}$} & \multicolumn{2}{|c|}{$\begin{array}{l}2^{\text {nd }} \text { harvest } \\
(140 \text { DAP) }\end{array}$} & \multicolumn{2}{|c|}{$\begin{array}{l}3^{\text {rd }} \text { harvest } \\
(160 \text { DAP) }\end{array}$} & \multicolumn{2}{|c|}{$\begin{array}{l}4^{\text {th }} \text { harvest } \\
\text { (180 DAP) }\end{array}$} \\
\hline & $\begin{array}{c}\text { Ajase-Ipo } \\
\text { (t/ha) }\end{array}$ & $\begin{array}{c}\text { Ifon } \\
\text { (t/ha) }\end{array}$ & $\begin{array}{c}\text { Ajase-Ipo } \\
\text { (t/ha) }\end{array}$ & $\begin{array}{c}\text { Ifon } \\
\text { (t/ha) }\end{array}$ & $\begin{array}{c}\text { Ajase-Ipo } \\
\text { (t/ha) }\end{array}$ & $\begin{array}{c}\text { Ifon } \\
\text { (t/ha) }\end{array}$ & $\begin{array}{c}\text { Ajase-Ipo } \\
\text { (t/ha) }\end{array}$ & $\begin{array}{c}\text { Ifon } \\
\text { (t/ha) }\end{array}$ \\
\hline Nursery & $13.5 a$ & $15.8 \mathrm{a}$ & $12.9 a$ & $14.8 \mathrm{a}$ & $10.3 a$ & $13.1 \mathrm{a}$ & $8.6 a$ & $11.8 \mathrm{a}$ \\
\hline Sprouted roots & $8.9 b$ & $9.4 b$ & $6.2 b$ & $4.6 b$ & $4.4 b$ & $3.9 b$ & $2.8 \mathrm{~b}$ & $2.6 b$ \\
\hline Successive planting & $6.9 b$ & $7.3 b$ & $5.8 b$ & $4.1 b$ & $4.8 b$ & $3.1 b$ & $1.6 \mathrm{~b}$ & $2.3 b$ \\
\hline
\end{tabular}

Means having the same letter are not significantly different $(P=0.05)$ according to Duncan's Multiple Range Test.

The combined effects of vines production methods and time of harvest on the average harvest index of tubers.

The combination of the methods of vines production and the time of harvest effects significantly $(P<0.05)$ affected the average harvest index of tuber at Ajase Ipo and Ifon (Table 6). Consistently, nursery method gave the significantly highest values [(71.9 and 72.8), (62.7 and $60.8 \%)$, (54.6 and $50.3 \%$ ) and (45.9 and $43.5 \%)]$ at Ajase Ipo and Ifon at 120, 140, 160, and 180 DAP respectively compared to sprouted roots and successive planting methods.

The significantly least values [(43.2 and $42.7 \%),(35.9$ and $32.3 \%)$, (24.6 and $27.2 \%)$ and (19.6 and $22.7 \%)$ ] at Ajase Ipo and Ifon 120, 140, 160, and 180 DAP respectively were recorded for successive planting method. The results showed that regarded to the time of harvest, the production of vines under nursery method gave the highest tubers and the fresh above biomass yield.
The combined effects of vines production methods and time of harvest on the average weight of weevil free marketable tubers and badly infected marketable tubers

The combination of the methods of vines production and the time of harvest effects significantly $(P<0.05)$ affected the average weight of weevil free marketable tubers and badly infected marketable tubers at Ajase Ipo and Ifon (Tables 7 and 8). Consistently, nursery method gave the significantly highest values [(13.5 and $15.8 \mathrm{t} / \mathrm{ha}),(12.9$ and $14.8 \mathrm{t} / \mathrm{ha}),(10.3$ and $13.1 \mathrm{t} / \mathrm{ha})$ and (8.6 and 11.8 t/ha)] weevil free marketable tubers at Ajase Ipo and Ifon at $120,140,160$, and 180 DAP respectively compared to sprouted roots and successive planting methods that were not significantly different from each other. But, the least values [(6.9 and 7.3 t/ha), (5.8 and $4.1 \mathrm{t} / \mathrm{ha})$, (4.8 and $3.1 \mathrm{t} / \mathrm{ha}$ ) and (1.6 and $2.3 \mathrm{t} / \mathrm{ha})$ ] at Ajase Ipo and Ifon at $120,140,160$, and 180 DAP respectively were recorded for successive planting method (Table 7). Table 8 indicates that, the combination the methods 
Table 8: The combined effects of vines production methods and time of harvest on the average weight of weevil badly infested marketable tubers of sweet potato in 2008 and 2009 at Ajase-Ipo, Kwara state and Ifon, Ondo state.

\begin{tabular}{|c|c|c|c|c|c|c|c|c|}
\hline \multirow{3}{*}{ Treatments } & \multicolumn{8}{|c|}{ Days to harvest of tubers } \\
\hline & \multicolumn{2}{|c|}{$\begin{array}{l}1^{\text {st }} \text { harvest } \\
(120 \text { DAP) }\end{array}$} & \multicolumn{2}{|c|}{$\begin{array}{l}2^{\text {nd }} \text { harvest } \\
\text { (140 DAP) }\end{array}$} & \multicolumn{2}{|c|}{$\begin{array}{l}3^{\text {rd }} \text { harvest } \\
(160 \text { DAP) }\end{array}$} & \multicolumn{2}{|c|}{$\begin{array}{l}4^{\text {th }} \text { harvest } \\
\text { (180 DAP) }\end{array}$} \\
\hline & $\begin{array}{c}\text { Ajase-Ipo } \\
\text { (t/ha) }\end{array}$ & $\begin{array}{l}\text { Ifon } \\
\text { (t/ha) }\end{array}$ & $\begin{array}{c}\text { Ajase-Ipo } \\
\text { (t/ha) }\end{array}$ & $\begin{array}{l}\text { Ifon } \\
\text { (t/ha) }\end{array}$ & $\begin{array}{c}\text { Ajase-Ipo } \\
\text { (t/ha) }\end{array}$ & $\begin{array}{c}\text { Ifon } \\
\text { (t/ha) }\end{array}$ & $\begin{array}{c}\text { Ajase-Ipo } \\
\text { (t/ha) }\end{array}$ & $\begin{array}{l}\text { Ifon } \\
\text { (t/ha) }\end{array}$ \\
\hline Nursery & $0.2 b$ & $0.3 b$ & $0.2 \mathrm{~b}$ & $0.7 \mathrm{~b}$ & $0.9 \mathrm{~b}$ & $1.2 \mathrm{~b}$ & $1.7 b$ & $1.9 \mathrm{~b}$ \\
\hline Sprouted roots & $0.9 a$ & $1.0 \mathrm{a}$ & $0.9 a$ & $1.3 a$ & $1.9 a$ & $2.5 \mathrm{a}$ & $3.6 a$ & $3.8 \mathrm{a}$ \\
\hline Successive planting & $1.1 \mathrm{a}$ & $1.2 \mathrm{a}$ & $1.6 a$ & $1.5 a$ & $2.2 \mathrm{a}$ & $2.8 \mathrm{a}$ & $4.0 \mathrm{a}$ & $4.2 \mathrm{a}$ \\
\hline
\end{tabular}

Means having the same letter are not significantly different $(P=0.05)$ according to Duncan's Multiple Range Test.

of vines production and the time of harvest effects significantly $(P<0.05)$ affected the average weight of badly infected marketable tubers at Ajase Ipo and Ifon. Consistently, nursery method gave the significantly least values [(0.2 and $0.3 \mathrm{t} / \mathrm{ha}),(0.2$ and $0.7 \mathrm{t} / \mathrm{ha}),(0.9$ and 1.2 t/ha) and (1.7 and 1.9 t/ha)] at Ajase Ipo and Ifon at 120, 140,160 , and 180 DAP respectively compared to sprouted roots and successive planting methods that were not significantly different from each other, which gave the significantly higher weight. It has been reported that older portions of cuttings as it was in the cases of cuttings from the rooted sprouts and successive planting are usually severely infested with weevils, while younger cuttings as it was in the case of nursery method of vines production are rarely infected with weevils (AVRDC, 1990; Lima and Morale, 1992). This notion is supported by a field study, which showed increase in number of weevils in vines with the increased in vines age (AVRDC, 1990).

\section{CONCLUSION AND RECOMMENDATION}

In this study, production of vines for propagation through nursery method enhanced the yield of marketable tubers, total fresh tubers yield, tubers dry matter content and tubers yield index in sweet potato. This method allows for the propagation of healthy, pests and diseases free cuttings unlike sourcing for the planting materials from sprouted roots and successive planting methods. Harvesting vines from successive planting for further propagation reduced yields of marketable tubers of sweet potato. Similarly, tuber quality of sweet potato was significantly reduced when cuttings were taking from sprouted roots and successive planting for propagation. Weevils that survived in stems of successive planting and tubers of sprouted roots will infect newly established sweet potato farms if planting materials were to be sourced from sprouted roots and successive planting methods. To overcome the problems of low yield and weevil infestation of sweet potato marketable tubers, new field must be propagated with the vines produced from the nursery method of vines production.

\section{REFERENCE}

Asian Vegetable Research and Development Center (AVRDC). AVRDC Progress Report Summaries 1990, Asian Vegetable Research and Development Center, Shanhua, Taiwan, 1990.

Bolaji OS, Elkanah FA, Ojo JA, Ojurongbe O, Adeyeba OA (2015). Prevalence and Intensity of Schistosoma haematobium among school children in Ajase-Ipo, Kwara State, Nigeria. Asian J. Biomedical and Pharmaceutical Sci., 5(43), 2015, 06-11.

Collins WW (1984). Progress in development sweet potato (Ipomoea batatas (L) Lam.) cultivars for fuel alcohol production. In: F.S.Shideler \& H.Rincon (eds.) Proc. 6th symp. Int. Soc. Trop. Root Crops, CIP, Lilm, Peru, p 571-575.

Duncan DB (1955). Multiple range and multiple F test. Biometrics 11: 142 Food and nutrition paper No 20.

Food and Agriculture Organization of the United Nations (2010). FAOSTAT. 1 May 2011.<http://faostat.fao.org/site/567/ default.aspx\#ancor>

Ikemoto S (1971). Studies on the direct planting of sweet potato, Bull, Chugoku National Argic. Exp., Stat. No. 20, 117-156.

Klass DL (1998). Biomass for renewable energy, fuels and chemicals. Elsevier, Sydney, Australia.

Kiozya HC, Mtunda K, Kapinga R, Chirimi B, Rwiza E (2001). Effect of leaf harvesting frequency on growth and yield of sweet potato in the Lake Zone of Tanzania. Afri. Crop Sci. J., 9(1): 97-103.

Lima M, Morales A (1992). Estudios Comparativos de Clones Precoces de Boniato [Ph.D. thesis], University "Marta Abreu" of Las Villas.

Loebenstein G, Thottappilly G (2009). The sweet potato. Springer, New York.

Mukhtar AA, Tanimu B, Arunah UL, Babaji BA (2010). Evaluation of the Agronomic Characters of Sweet Potato Varieties Grown at Varying Levels of Organic and Inorganic Fertilizer. World J. Agric. Sci. 6 (4): 370-373.

Nguyen BL, Bautista OK (1999). Extent and mechanism of yield reduction in sweet potato grown for tops and roots. Philos. Agric. 82: $137-150$

Nwinyi SCO (1992). Effect of age of shoot removal on tuber and shoot yields at harvest of five sweet potato (Ipomoea batatas (L) Lam.) cultivars. Field crops Res. 29(1): 47-54.

Oke MO, Workneh TS (2013). A review on sweet potato postharvest processing and preservation technology. African J. Agric. Res. 8(40), pp. 4990- 5003.

Onwueme IC (1978). The tropical tuber crops. Yam, Cassava, Sweet potato and Cocoyam. New York: John Wiley and Sons. 
036 Int. Res. J. Agric. Sci. Soil Sci.

Posas OB (1989). Sweet potato as animal feed. Radix 11, 1-8. ShanmugavelU KG, Thamburaj S, Shanmugam A, Gopalaswamy N (1972). Effect of time of planting and typeof planting material on the yield of sweet potato (Ipomoea batatas). South India Horticulture20, 55-58.

Snedecor GW, Cochran WG (1967). Statistical Methods. Iowa University, Press. Ames. lowa, pp: 507.

Stathers T, Namanda S, Mwanga ROM, Khisa G, Kapinga R (2005). Manual for Sweet Potato Integrated Production and Pest Management for Farmer Field Schools in Sub-Saharan Africa. Intl. Potato Centre, CIP, Kampala. P.31. ISBN 9970-895-01-x.

U.S. Sweet Potato Council. 2011. The United States Sweet Potato Council Inc.1 May 2011. <www.sweetpotatousa.org>.

Ziska LH, Runion GB, Tomecek M, Prior SA, Torbet HA, Sicher R (2009). An evaluation of cassava, sweet potato and field corn as potential carbohydrate sources for bioethanl production in Alabama and Maryland. Biomass Bioenergy 33:1503-1508. 